\title{
Assessment of Gas Hydrate Resources on the North Slope, Alaska, 2008
}

The U.S. Geological Survey (USGS) recently completed the first assessment of the undiscovered technically recoverable gashydrate resources on the North Slope of Alaska. Using a geologybased assessment methodology, the USGS estimates that there are about 85 trillion cubic feet (TCF) of undiscovered, technically recoverable gas resources within gas hydrates in northern Alaska.

\section{Introduction}

U.S. Geological Survey (USGS) scientists have completed the first assessment of the undiscovered, technically recoverable gas-hydrate resources beneath the North Slope of Alaska. This assessment indicates the existence of technically recoverable gas-hydrate resources-that is, resources that can be discovered, developed, and produced using current technology. The assessment is based on the geologic elements used to define a Total Petroleum System (TPS), including hydrocarbon source rocks (source-rock type and maturation and hydrocarbon generation and migration), reservoir rocks (sequence stratigraphy, petrophysical properties, seismic attribute development, and prospecting), and hydrocarbon traps (trap formation and timing). The area assessed in northern Alaska (fig. 1) extends from the National Petroleum Reserve in Alaska (NPRA) on the west through the Arctic National Wildlife Refuge (ANWR) on the east and from the Brooks Range northward to the State-Federal offshore boundary (located three miles north of the coastline). This area consists mostly of Federal, State, and Native lands covering about 55,894 $\mathrm{mi}^{2}$.

Approximately 35 years ago, Russian scientists made what was then a bold assertion that gas hydrates, long a curiosity of physical chemists, should occur in nature. Since then, the USGS and others have built a strong scientific foundation supporting the conclusion that gas hydrates are a global phenomenon containing potentially huge volumes of gas in terrestrial polar regions and the deep water portions of most continental margins. Gas hydrates are naturally occurring, ice-like solids in which water molecules trap gas molecules in a cage-like structure known as a clathrate. Although many gases form hydrates in nature, methane hydrate is by far the most common. In 1995, the USGS conducted the first systematic assessment of the in-place natural gas-hydrate resources of the United States (Collett, 1995). That study suggested that the amount of gas in the Nation's hydrate accumulations greatly exceeds the

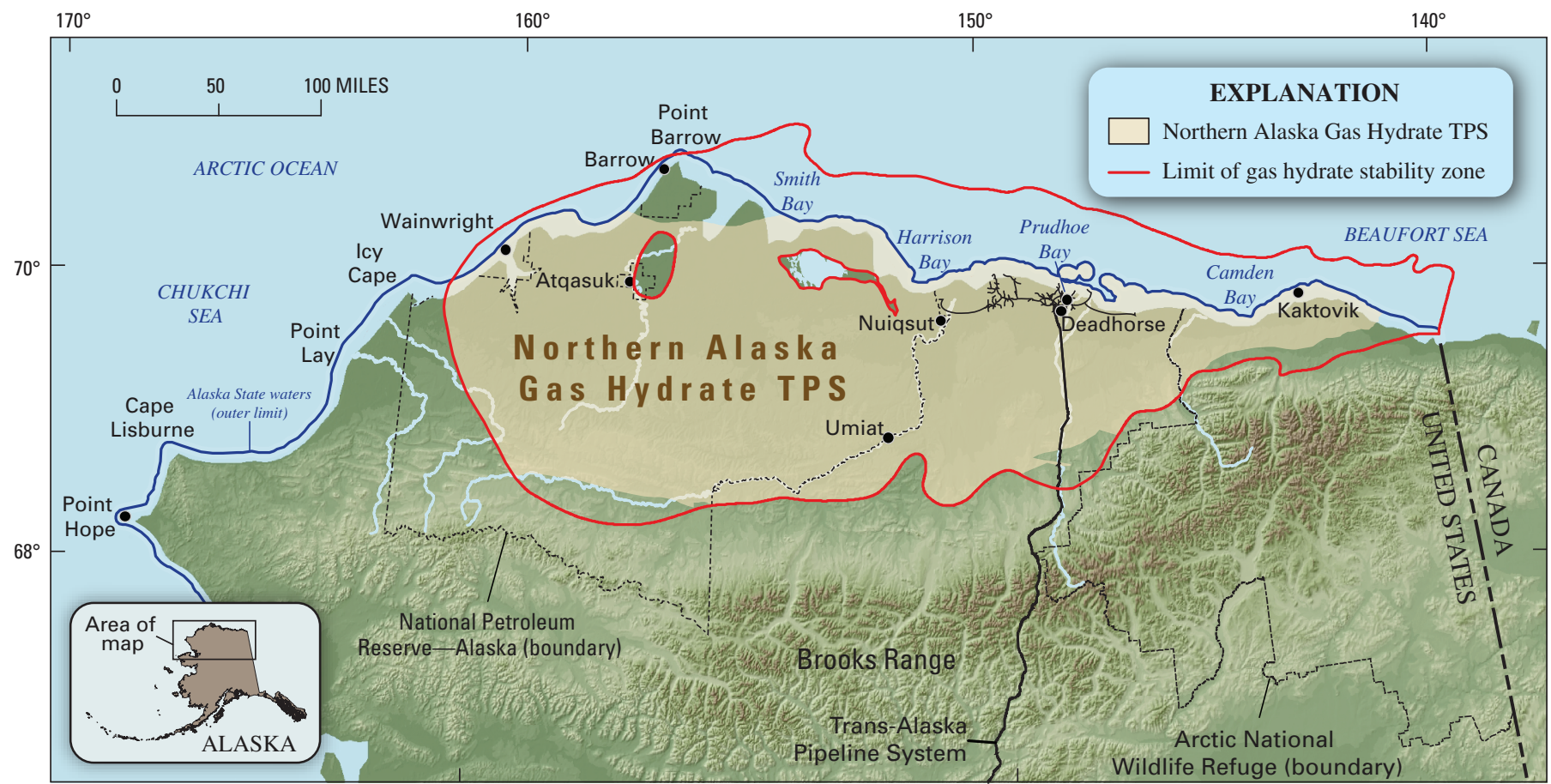

Figure 1. The Northern Alaska Gas Hydrate Total Petroleum System (TPS) (shaded in tan), and the limit of gas hydrate stability zone in northern Alaska (red outline). 
volume of known conventional domestic gas resources. The 1995 USGS assessment also estimated that the permafrostassociated gas hydrates on the Alaska North Slope may contain as much as 590 trillion cubic feet (TCF) of in-place gas. Two large gas hydrate accumulations have been identified near the Prudhoe Bay Oil Field. The in-place volume of gas estimated within the known gas hydrates of the Prudhoe Bay-Kuparuk River infrastructure area alone may exceed 100 TCF. However, it is important to note that none of the previously published gas hydrate assessments have predicted how much gas could actually be produced from the gas hydrate accumulations in northern Alaska.

In recognition of the importance of gas hydrates as a potential energy resource, the USGS and the U.S. Bureau of Land Management (BLM) entered into an Assistance Agreement in 2002 to assess the volume of gas that could be produced from gas hydrates in northern Alaska. The primary objective of this assessment was to conduct a geology-based analysis of the occurrence of gas hydrates within northern Alaska to determine the role gas hydrate may play as a future domestic-energy resource. This project included three concurrent phases. Phase I focused on the Eileen gas hydrate occurrences overlying the Prudhoe Bay, Kuparuk River, and Milne Point oil fields. Phase II dealt with identifying and characterizing potential gas hydrate accumulations on federallymanaged lands in NPRA and ANWR, and on lands managed by the State of Alaska between the Colville and Canning Rivers. Phase III entailed a systematic, geology-based appraisal of the volume of gas that can be technically produced from gas hydrates on the North Slope.

\section{Geologic Definition of Assessment Units}

The Northern Alaska Gas Hydrate TPS (fig. 1) includes Cretaceous and Tertiary reservoir rocks that have been divided into three assessment units (AUs) - from oldest to youngest, the Nanushuk Formation Gas Hydrate AU, the Tuluvak-Schrader Bluff-Prince Creek Formations Gas Hydrate AU, and the Sagavanirktok Formation Gas Hydrate AU.

The geologic model used to define the AUs and assess the gas hydrate resources involved defining and characterizing the components of the petroleum system controlling the occurrence of gas hydrate accumulations in each AU. As a first step, the factors controlling gas hydrate phase equilibria, mostly a function of formation temperature and pressure, were assessed to map the spatial distribution of the gas hydrate stability zone in northern Alaska (fig. 1). Characterization of the potential reservoir rocks within the mapped gas hydrate stability zone yielded the three AUs defined in this study. Only gas hydrates lying below the permafrost section were assessed, thus limiting the AUs to the stratigraphic interval below the base of the permafrost and above the base of the gas hydrate stability zone. Free-gas potentially trapped below the gas hydrate stability zone was not assessed. Also, as part of the gas hydrate petroleum system assessment, geochemical analysis of known gas hydrate occurrences revealed a link between gas hydrate accumulations and more deeply buried conventional oil and gas occurrences, in which methane migration from depth has charged the reservoir rocks in the gas hydrate stability zone. These geochemical studies have been used to further characterize and constrain the occurrence and distribution of the potential gas hydrate accumulations on the North Slope. The conventional gas fields in the Barrow area were not considered to contain gas hydrate in this study.

For the first time, the USGS has assessed gas hydrates, a traditionally unconventional resource with no confirmed production history, as a producible resource occurring in discrete hydrocarbon traps and structures. The approach used to assess the gas hydrate resources in northern Alaska followed standard geology-based USGS assessment methodologies developed to assess conventional oil and gas resources. In order to use the USGS conventional assessment approach on gas hydrate resources, it was documented through the analysis of threedimensional industry-acquired seismic data that the gas hydrates on the North Slope occupy limited, discrete volumes of rock bounded by faults and downdip water contacts (fig. 2). For the most part, it appears that the seismically-imaged gas hydrate accumulations were once conventionally trapped free-gas

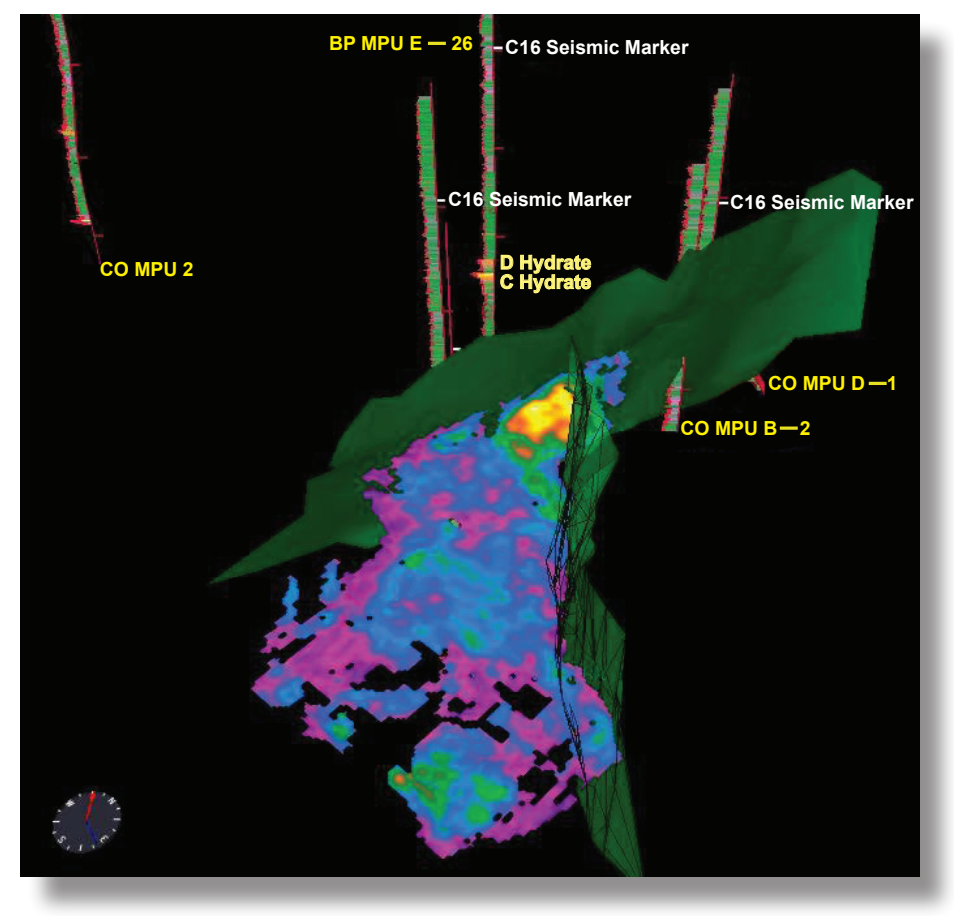

Figure 2. Milne Point-Mount Elbert gas hydrate prospect. Threedimensional image of a fault-bounded, high amplitude feature (in a pallet of colors ranging from yellow to magenta; the yellowimaged portion of the structure contains the thickest and most concentrated gas hydrate). Also shown are the bounding faults (in green) and gas hydrate occurrences in nearby well penetrations. The well penetrations show downhole-measured geophysical data indicative of gas hydrate occurrence (in yellow). 
accumulations that were converted to gas hydrate at the onset of cold arctic conditions at the beginning of the Pliocene (about $1.88 \mathrm{Ma})$.

The USGS conventional assessment approach also assumes that the hydrocarbon resource being assessed can be produced by existing conventional technology. The production potential of the known and seismically inferred gas-hydrate accumulations in northern Alaska has not been adequately field tested, but has been the focus of a U.S. Department of Energy led industry research effort. Although verified by only limited field testing, numerical production models of gas hydrate-bearing reservoirs overlying the Milne Point and Prudhoe Bay oil fields suggest that gas can be produced from gas hydrate with existing conventional technology. Among the various techniques for production of natural gas from gas hydrates, depressurization appears to be the most promising method. Gas production rates reported from recent gas hydrate testing at the Canadian Mallik site compare favorably with the modeled production rates predicted for the gas hydrate occurrences in northern Alaska (Anderson and others, 2008). A growing body of evidence indicates that concentrated gas hydrate accumulations in conventional hydrocarbon reservoirs, such as those in northern Alaska, can be produced with existing technology.

Two of the critical components of the USGS assessment procedure are the accurate prediction of the expected size and number of undiscovered hydrocarbon accumulations. This assessment of the gas hydrate resources on the North Slope relied heavily on the analysis of industry-acquired threedimensional seismic data, which was used to characterize the size, number and distribution of gas hydrate accumulations in each of the three AUs. The minimum accumulation size considered was 20 billion cubic feet of technically recoverable gas. This minimum accumulation size is smaller than those used in other USGS assessments in northern Alaska, in recognition that most of the seismically inferred gas-hydrate accumulations occur in close association in stacked reservoir sections and would likely be produced together from the same wells and production facilities.

\section{Resource Summary}

The USGS assessment strategy provides estimates of the volumes of undiscovered petroleum resources that are technically recoverable (table 1). For the Northern Alaska Gas Hydrate TPS, the USGS estimates that the total undiscovered natural gas resources in gas hydrate range between 25.2 and 157.8 trillion cubic feet (TCF; 95-percent and 5-percent probabilities of greater than these amounts, respectively), with a mean estimate of 85.4 TCF. Of this mean estimate, (1) about 24 percent (20.6 TCF) is in the Sagavanirktok Formation Gas Hydrate AU, (2) 33 percent (28.0 TCF) is within the TuluvakSchrader Bluff-Prince Creek Formations Gas Hydrate AU, and (3) 43 percent (36.9 TCF) is in the Nanushuk Formation Gas Hydrate AU (table 1). Given that relatively few wells have penetrated the expected gas hydrate accumulations in these three AUs, there is significant geologic uncertainty in these estimates, which is reflected in the range of estimates in table 1.

The mean estimate of $85.4 \mathrm{TCF}$ of gas within the gas hydrates of northern Alaska is considerably less than the 590 TCF reported in the 1995 USGS assessment. It is critical to note that the 1995 assessment only dealt with estimating the in-place volume of gas with hydrates, whereas this more recent assessment dealt only with technically recoverable gas. Also, the 1995 assessment included the offshore Federal waters (fig. 1), which were not included in this assessment. In addition, the assessment results reported here are based on geologic data that were

Table 1. Alaska North Slope-Gas hydrate assessment results.

[BCFG, billion cubic feet of gas. MMBNGL, million barrels of natural gas liquids. Results shown are fully risked estimates. F95 represents a 95-percent chance of at least the amount tabulated; other fractiles are defined similarly. Fractiles are additive, assuming perfect positive correlations. NGL, natural gas liquids; TPS, total petroleum system; AU, assessment unit.]

\begin{tabular}{|c|c|c|c|c|c|c|c|c|c|}
\hline \multirow{2}{*}{$\begin{array}{l}\text { Total Petroleum System } \\
\text { and Assessment Unit }\end{array}$} & \multirow{2}{*}{$\begin{array}{l}\text { Field } \\
\text { Type }\end{array}$} & \multicolumn{8}{|c|}{ Total Undiscovered Resources } \\
\hline & & \multicolumn{4}{|c|}{ Gas (BCFG) } & \multicolumn{4}{|c|}{ NGL (MMBNGL) } \\
\hline \multicolumn{10}{|l|}{ Northern Alaska Gas Hydrate TPS } \\
\hline $\begin{array}{l}\text { Sagavanirktok Formation } \\
\text { Gas Hydrate AU }\end{array}$ & Gas & 6,285 & 19,490 & 37,791 & 20,567 & 0 & 0 & 0 & 0 \\
\hline $\begin{array}{l}\text { Tuluvak-Schrader Bluff-Prince } \\
\text { Creek Formations Gas Hydrate } \\
\text { AU }\end{array}$ & Gas & 8,173 & 26,532 & 51,814 & 28,003 & 0 & 0 & 0 & 0 \\
\hline $\begin{array}{l}\text { Nanushuk Formation Gas } \\
\text { Hydrate AU }\end{array}$ & Gas & 10,775 & 35,008 & 68,226 & 36,857 & 0 & 0 & 0 & 0 \\
\hline
\end{tabular}


not previously available, which afforded a greatly improved appreciation of the North Slope gas hydrate petroleum system.

This research reflects ongoing efforts by USGS and BLM scientists and land managers to provide the Nation and its decision makers with reliable data as a basis for future energy policy.

\section{References}

Anderson, B.J., Wilder, J.W., Kurihara, M., White, M.D., Moridis, G.J., Wilson, S.J., Pooladi-Darvish, M., Masuda, Y., Collett, T.S., Hunter, R.B., Narita, H., Rose, K., and Boswell, R., 2008, Analysis of modular dynamic formation test results from the Mount Elbert 01 stratigraphic test well, Milne Point Unit, North Slope Alaska: Proceedings of the 6th International Conference on Gas Hydrates (ICGH 2008), July 6-10, 2008, Vancouver, British Columbia, Canada, 13 p. (on CD-ROM).

Collett, T.S., 1995, Gas hydrate resources of the United States, in Gautier, D.L., Dolton, G.L., Takahashi, K.I., and Varnes, K.L., eds., 1995 National assessment of United States oil and gas resources_results, methodology, and supporting data: U.S. Geological Survey Digital Data Series 30 (on CD-ROM).

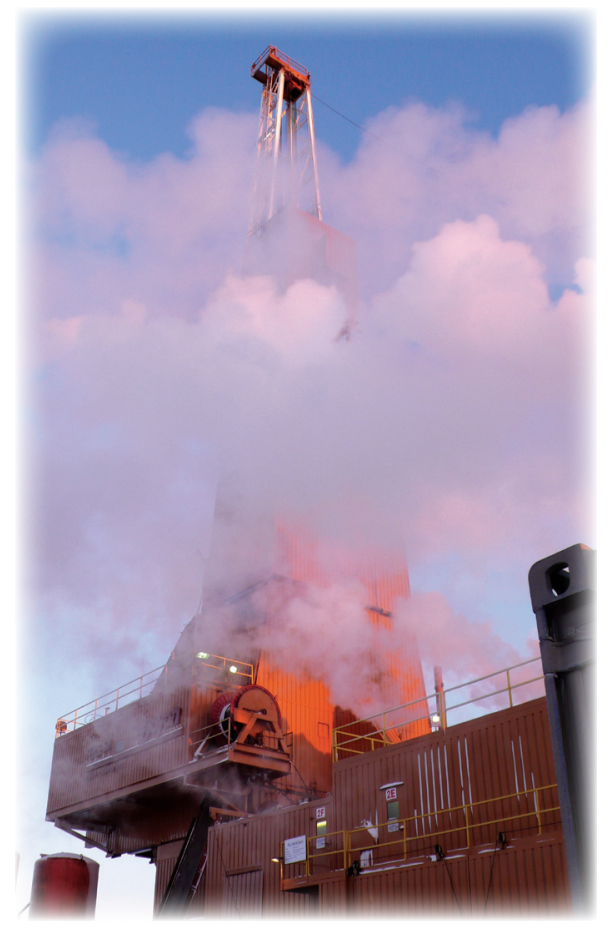

\section{North Slope Gas Hydrate Assessment Team}

Timothy S. Collett, Warren F. Agena, Myung W. Lee, Margarita V. Zyrianova, Kenneth J. Bird, Ronald R. Charpentier, Troy Cook, David W. Houseknecht, Timothy R. Klett, Richard M. Pollastro, and Christopher J. Schenk.

\section{Acknowledgments}

The research project in support of this assessment was a cooperative effort with the Bureau of Land Management. The technical and management contributions of Bob Fisk, BLM Program Manager, and Beth Maclean, BLM Program Assistant, are acknowledged and greatly appreciated.

\section{For further information}

This factsheet and assessment results are available at the USGS Energy Program website, http://energy.usgs.gov, or contact Timothy S. Collett, Task Leader for the USGS North Slope of Alaska Gas Hydrate Assessment (tcollett@usgs.gov).
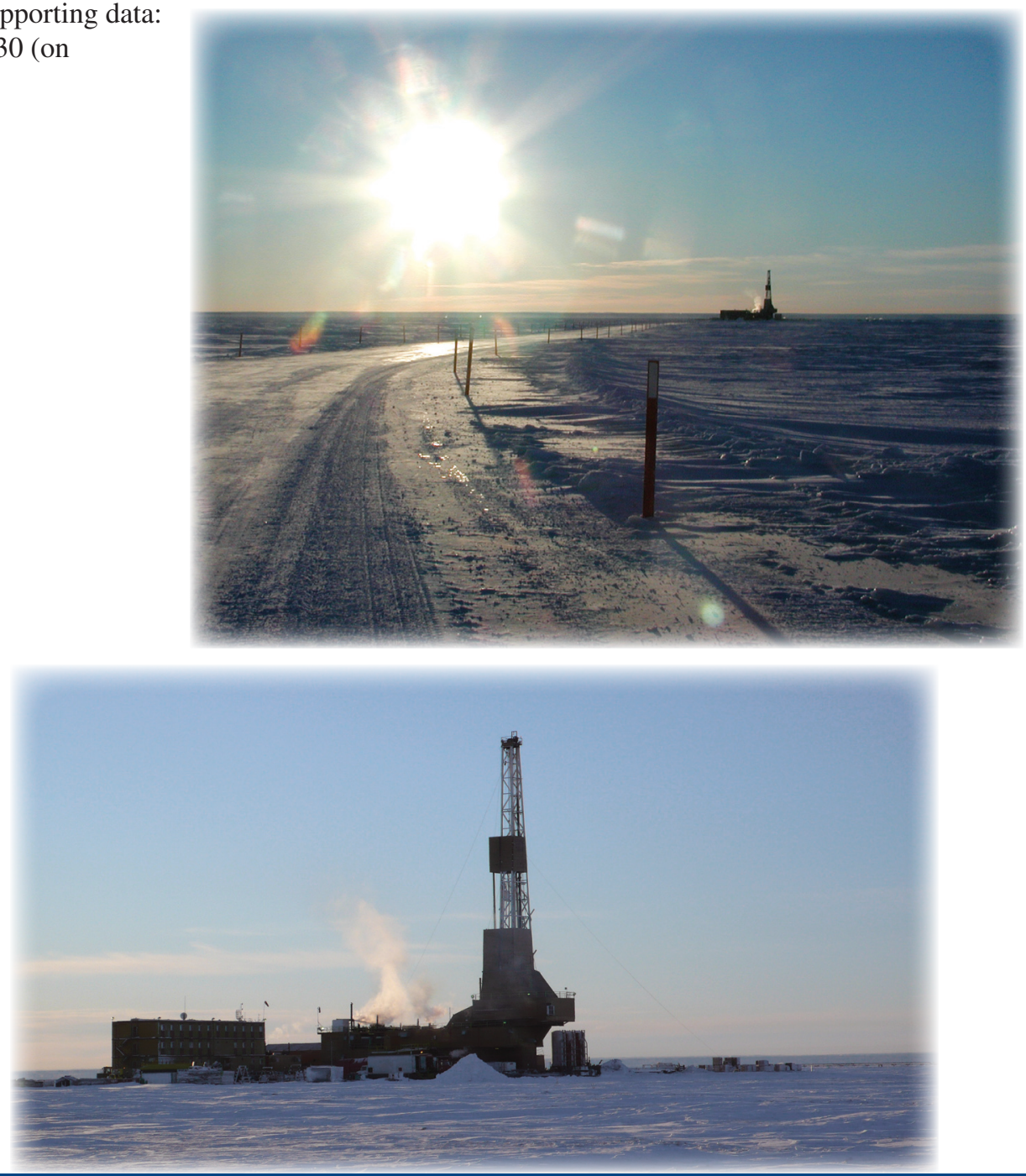